\title{
Effects of Nano-Iron Oxide Particles on Agronomic Traits of Soybean
}

\author{
Roghayyeh SHEYKHBAGLOU ${ }^{1)}$,Mohammad SEDGHI ${ }^{1)}$, Mehdi \\ TAJBAKHSHSHISHEVAN ${ }^{2}$, RaufSEYED SHARIFI') \\ ${ }^{1)}$ University of Mohaghegh Ardabili, Faculty of Agriculture, Department of Agronomy and Plant Breeding, Ardabil, Iran; mosedghi2003@yahoo.com \\ ${ }^{2)}$ University of Urmia, Faculty of Agriculture, Department of Agronomy and Plant Breeding, Urmia, Iran
}

\begin{abstract}
This study was performed to determine the effect of nano-iron oxide on soybean yield and quality. Field experiment was designed based on randomized complete block design with three replications. Treatments were five levels of nano-iron oxide $(0,0.25,0.5,0.75$ and $\left.1 \mathrm{gl}^{-1}\right)$. Results showed that nano-iron oxide at the concentration of $0.75 \mathrm{~g} \mathrm{l}^{-1}$ was increased leaf + pod dry weight and pod dry weight. The highest grain yield was observed with using $0.5 \mathrm{gl}^{-1}$ nano-iron oxide that showed $48 \%$ increase in grain yield in comparison with control. Other measured traits were not affected by the iron nano- particles.
\end{abstract}

Keywords: nano-iron oxide, soybean, pod dry weight

\section{Introduction}

Soybean (Glycine max (L) Merr.) belongs to Fabaceae family and is an annual crop. Due to having useful compounds such as unsaturated fatty acids, protein, mineral salts and plant secondary metabolites such as isoflavin, soya bean has many important roles in human and animal nutrition. Achieving optimum quantity and increasing quality of soybean seeds depend upon many factors among which, weed control and plant nutrition have critical importance (Sedghi, 2007). Iron is one of the essential elements for plant growth and plays an important role in the photosynthetic reactions. Iron activates several enzymes and contributes in RNA synthesis and improves the performance of photosystems (Malakouti and Tehrani, 2005). Soybean is sensitive to iron deficiency, but different genotypes are various in efficiency of iron consumption. Application of iron in low-iron soils can increase grain yield in soybean (Ghasemi et al, 2006). Iron compounds can use as foliar on leaves and as seed coating (Debermann, 2006). Nanotechnology can present solution to increasing the value of agricultural products and environmental problems. With using of nano-particles and nano-powders, we can produce controlled or delayed releasing fertilizers. Nano-particles have high reactivity because of more specific surface area, more density of reactive areas, or increased reactivity of these areas on the particle surfaces. These features simplify the absorption of fertilizers and pesticides that produced in nano scale (Anonymous, 2009). There are a few reviews about the effects of nano-particles on plants. Studies showed that the effect of nano-particles on plants can be beneficial (seedling growth and development) or non-beneficial (to prevent root growth) (Zhu et al, 2008). This experiment was conducted to investigate the effects of nano-iron oxide particles on soybean yield and agronomic traits.

\section{Materials and methods}

This field experiment was conducted on clay soil in Agricultural Research Station of Urmia University during 2009-2010 growing season to investigate the effects of nano-iron oxide on yield and agronomic traits of soybean (cultivar 'L17'). Urmia is located on the north-west of Iran with 1320 meters altitude, $45^{\circ} 5^{\prime}$ longitude, and $37^{\circ} 32^{\prime}$ latitude. According to soil analysis performed prior to sowing, the $\mathrm{pH}$ of soil was 7.6 and electrical conductivity (EC) of extract was $1.1 \mathrm{ds} \cdot \mathrm{m}^{-1}$ soil texture was clay. The experimental design was randomized complete block design with three replications. Treatments were controlled (without nano-iron oxide application) and 4 levels of nano-iron oxide application including $0.25,0.5$, 0.75 and $1 \mathrm{~g} \mathrm{l}^{-1}$. Soybean seeds were inoculated with $\mathrm{Bra}$ dyrhizobium japonicum before planting. Nano-iron oxide were sprayed at three stages including 4 leaves (V4 in Fehr and Caviness (1977) scale), 8 leaves (V8) and grain filling stage (R4). In order to determine the pod weight, at the time of harvest, four plants from each plot were sampled and four pods per plant were selected. After determining fresh weight, pods were placed in the oven with at $48^{\circ} \mathrm{C}$ for 48 hours and then were weighted with four digits scale. At the end of the growing season and after the browning of pods, plants were harvested from $2 \mathrm{~m}^{2}$ considering the border effect. Ten randomly selected plants per plot from harvested samples were used to measure desired characteristics. The statistical procedure was performed by SAS 9.1 computer software and means were compared by Duncan's multiple range test. 


\section{Results and discussion}

Results showed that the effect of nano-iron oxide on the leaf plus dry pod weight was significant (Tab. 1). At the same time, the effect of nano-iron oxide on dry pod weight during the final stage of growth was significant (Tab. 1). Application of nano-iron oxide at the concentration of $0.75 \mathrm{~g} \mathrm{l}^{-1}$ caused an increase in dry pod weight and dry weight of leaf plus pod (Tab. 2). Researchers have and yield. Application of nano-iron oxide at $0.75 \mathrm{gl}^{-1} \mathrm{com}-$ pare to other treatments had maximum effect on dry pod weight. It seems that the use of iron nano-particles causes increasing in pod and dry leaf weight and finally will increase total yield. Before the recommendation of these materials, additional testing is required and influence of the nano-particles on soybean products must be evaluated.

This research is continuing for determining of the effects of nano-iron oxide on soybean grain quality.

Tab. 1. Analysis of variance for traits in soybean

\begin{tabular}{cccccccccccccc}
\hline SOV & df & $\begin{array}{c}\text { Plant } \\
\text { height }\end{array}$ & $\begin{array}{c}\text { Plant } \\
\text { diameter }\end{array}$ & $\begin{array}{c}\text { No. of } \\
\text { sub- } \\
\text { branches }\end{array}$ & $\begin{array}{c}\text { No. of } \\
\text { filled pod/ } \\
\text { plant }\end{array}$ & $\begin{array}{c}\text { Hollow pod } \\
\text { number/ } \\
\text { plant }\end{array}$ & $\begin{array}{c}\text { Total no. } \\
\text { of grains } \\
\text { per plant }\end{array}$ & $\begin{array}{c}\text { Total } \\
\text { grain } \\
\text { weight }\end{array}$ & $\begin{array}{c}\text { Shoot } \\
\text { weight }\end{array}$ & $\begin{array}{c}\text { Leaf } \\
+ \text { pod } \\
\text { weight }\end{array}$ & $\begin{array}{c}100 \\
\text { grain } \\
\text { weight }\end{array}$ & $\begin{array}{c}\text { Pod dry } \\
\text { weight }\end{array}$ & $\begin{array}{c}\text { Yield } \\
\text { neigs }\end{array}$ \\
\hline Replication & 2 & $2.1^{\text {ns }}$ & $0.012^{\text {ns }}$ & $0.46^{\text {ns }}$ & $293.06^{\text {ns }}$ & 68.6 & $3283.8^{\text {ns }}$ & $16.09^{\text {ns }}$ & $122.7^{*}$ & $6.7^{\text {ns }}$ & $0.61^{\text {ns }}$ & $0.009^{\circ}$ & $164.559^{\circ}$ \\
\hline Treatment & 4 & $46.2^{\text {ns }}$ & $0.008^{\text {ns }}$ & $0.26^{\text {ns }}$ & $570.6^{\text {ns }}$ & $21.16^{\text {ns }}$ & $4267.7^{\text {ns }}$ & $67.5^{\text {ns }}$ & $19.5^{\text {ns }}$ & $77.9^{\circ}$ & $0.57^{\text {ns }}$ & $0.002^{\circ}$ & $411.307^{* *}$ \\
Error & 8 & 38.04 & 0.005 & 1.21 & 840.5 & 10.26 & 5733.9 & 51.9 & 18.8 & 19.9 & 0.64 & 0.004 & 57.366 \\
\%CV & 5.9 & 2.4 & 13.02 & 20.3 & 21.3 & 20.5 & 15.9 & 17.1 & 10.8 & 5.9 & 5.11 & 9.54 \\
\hline
\end{tabular}

ns, ${ }^{* *}$ and ${ }^{*}$, are non-significant, significant at $1 \%$ and $5 \%$ level, respectively

Tab. 2. Effect of various concentrations of nano-iron oxide on some agronomic traits in soybean

\begin{tabular}{cccc}
\hline $\begin{array}{c}\text { Nano-iron } \\
\text { oxide }\left(\mathrm{g} \mathrm{lit}^{-1}\right)\end{array}$ & $\begin{array}{c}\text { Pod dry } \\
\text { weight }(\mathrm{g})\end{array}$ & $\begin{array}{c}\text { Leaf + pod dry } \\
\text { weight }(\mathrm{g})\end{array}$ & $\begin{array}{c}\text { Yield } \\
\left(\mathrm{g} \mathrm{m}^{-2}\right)\end{array}$ \\
\hline 0 & $0.41^{\mathrm{b}}$ & $32.35^{\mathrm{b}}$ & $60.94^{\mathrm{b}}$ \\
0.25 & $0.42^{\mathrm{ab}}$ & $42.35^{\mathrm{ab}}$ & $76.78^{\mathrm{ab}}$ \\
0.5 & $0.44^{\mathrm{ab}}$ & $42.45^{\mathrm{ab}}$ & $90.22^{\mathrm{a}}$ \\
0.75 & $0.48^{\mathrm{a}}$ & $45.84^{\mathrm{a}}$ & $88.33^{\mathrm{a}}$ \\
1 & $0.45^{\mathrm{ab}}$ & $42.32^{\mathrm{ab}}$ & $80.39^{\mathrm{ab}}$ \\
\hline
\end{tabular}

Means with different letters at each column have statistically different at $5 \%$ level

shown that the application of nano-iron oxide significantly affects peanut and causes increasing growth and photosynthesis. Nano-iron oxide compared to other treatments such as organic materials and iron citrate facilitated the photosynthate and iron transferring to the leaves of peanut (Liu et al, 2005). At the same time, the use of nano calcium carbonate compared to humic acid and organic fertilizer, caused more tillering in peanuts, and low concentrations of nano calcium carbonate caused increasing the number of leaf and leaf area, dry weight, soluble sugar and peanut protein (Liu et al, 2005). The use of iron fertilizer increased the mean of total iron concentration and total absorption of iron in soybean, but had no significant effect on copper concentration. Average concentrations of iron and phosphorus on the grain did not affect, but the ratio of phosphorus to iron increased (Ghasemi et al, 2006). Iron at concentration of $2.5 \mathrm{mg} \mathrm{kg}^{-1}$ in soil increased dry matter weight of soybean, but higher levels of iron decreased soybean growth (Chakralhoseini et al, 2002). The use of iron as Fe-EDDHA significantly increased the concentration and total absorption of iron in soybeans (Roomizadeh and Karimian, 1996).

\section{Conclusions}

Among the investigated traits, nano-iron oxide had significant effects on the dry pod weight; leaf plus dry pod,

\section{References}

Anonymous. (2009). Nano technology in agriculture. Journal of Agriculture and Technology 114: 54-65 (In Persian).

Chakralhoseini, M. R., A. Ronaghi, M. Mafton and N. A. Karimian (2002). Soybean response to application of iron and phosphorus in a calcareous soil. Science and Technology Journal of Agriculture and Natural Resources 6 (4):91-101.

Debermann, A.R. (2006). Extension soil fertility. In: Ferguson, R. B. Fertilizer recommendations for soybean.

Fehr, W. R. and C. E. Caviness, (1977). Stages of soybean development. Spec. Rep. 80. Iowa Agric. Home Econ. Exp. Stn., Iowa State Univ.

Ghasemi Fasaei, R., A. Ronaghi, M. Maftoun and N. A. Karimian (2006). Effect of Iron Chalate on seed yield and chemical composition of soybean genotypes. Journal of Agriculture 29(2):1-22.

Liu, X. M., F. D. Zhang, S. Q. Zhang, X. S. He, R. Fang, Z. Feng and Y. Wang (2005). Responses of peanut to nano-calcium carbonate. Plant Nutrition and Fertilizer Sci. 11:3-9.

Liu, X. M., F. D. Zhang, S. Q. Zhang, X. S. He, R. Fang, Z. Feng and Y. Wang (2005). Effects of nano-ferric oxide on the growth and nutrients absorption of peanut. Plant Nutr. and Fert. Sci. 11:14-18.

Malakouti, M. and M. Tehrani, (2005). Micronutrient role in increasing yield and improving the quality of agricultural products. $1^{\text {st }}$ ed. Tarbiat Modarres Press. Tehran.

Roomizadeh, S. and N. Karimian (1996). Mnganese-iron relationship in soybean grown in calcareous soils. Journal of Plant Nutrition 19:397-406.

Sedghi, M. (2007). Physiological effects of weed interference and different levels of fertilizers containing nitrogen on soybean cultivars. Ph.D. dissertation, Faculty of Agriculture, Tabriz University.

Zhu, H., J. Q. Han and Y. Jin (2008). Uptake, translocation, accumulation of manufactured iron oxide nanoparticles by pumpkin plants. J. Environ Monit. 10:713-717. 